\title{
The youth and old age of Dapi'chi (the Pleiades): frosts, air carnations, and warriors
}

\author{
Cecilia Paula Gómez
}

\author{
Faculty of Social Sciences, University of Buenos Aires, Marcelo T. de Alvear 2230, \\ Buenos Aires, Argentina \\ email: gomezcp@gmail.com
}

\begin{abstract}
Among the Western Tobas of the province of Formosa, Argentina, the asterism called Dapi'chi (the Pleiades) is highly important. Traditionally, it is related to the start of the annual cycle and it is also a very significant figure in terms of its symbolic meaning. In fact, this celestial representation offers a range of insights connected to winter frosts, a type of air carnation (Tillandsia spp.-Bromeliaceae) and also to the role of the warrior.
\end{abstract}

Keywords. Western Tobas, Formosa, Gran Chaco, Pleiades, air carnations, annual cycle, warriors

\section{Introduction}

The Toba groups with whom this article is concerned (see Fig. 1) have been called 'Toba-Pilagá' (Métraux 1937), 'Tobas from the middle course of the Pilcomayo', 'Tobas of Sombrero Negro', and 'Ñachilamole\#ek Tobas' (Arenas 2003). They are settled in the west of the province of Formosa, Argentina, and reside specifically in the Bermejo Department, at approximately $80 \mathrm{~km}$ from the city of Ingeniero Juarez. They have many fixed settlements - Vaca Perdida, La Rinconada and El Churchal being the most populous and a large number of seasonal settlements. According to a survey carried out in 1999 by the Civil Association Comlaje 'pi Naleua, almost 2000 people lived in these settlements (Arenas 2003: 41).

Among the Tobas, the star cluster called Dapi'chi (the Pleiades) is culturally important. This article will develop this topic further. Before plunging into the meanings and symbolisms attached to the Pleiades among the Western Tobas of the province of Formosa, we should reiterate some of the meanings relating to the asterism that have previously been recorded within other Tobas and Pilagá groups. Taking this into account, we will then be able to examine some of the similarities and differences in how these indigenous peoples understand Dapi'chi.

Let us start with the Tobas from Tartagal and Monte Caramelo, also called 'BolivianTobas'. They consider that Dapi'chi represents 'a high Uranus God' (Tomasini 1976). They also say that the Milky Way, among other things, was created by Dapi'chi. In the 1920s, the ethnologist Robert Lehmann-Nitsche mentioned three different ways of interpreting Dapi 'chi in the Toba linguistic system, which could be related to different collective traditions. Bear in mind that these three conceptions reflect the divisions that exists among the oriental Tobas, who do not comprise a homogenous group. The first identifies the Pleiades as a big bonfire (Lehmann-Nitsche 1924/5: 186), the second as some boys (ibid.: 189), and the third as carob flour dropped onto the ground around the mortar (Lehmann-Nitsche 1924: 268, 275). The same author states that the term can be decomposed into api, grandfather, and aschi, boss (Lehmann-Nitsche 1924/5: 189). According to Lehmann-Nitsche, the translation 'our grandfather, the boss' implies an 


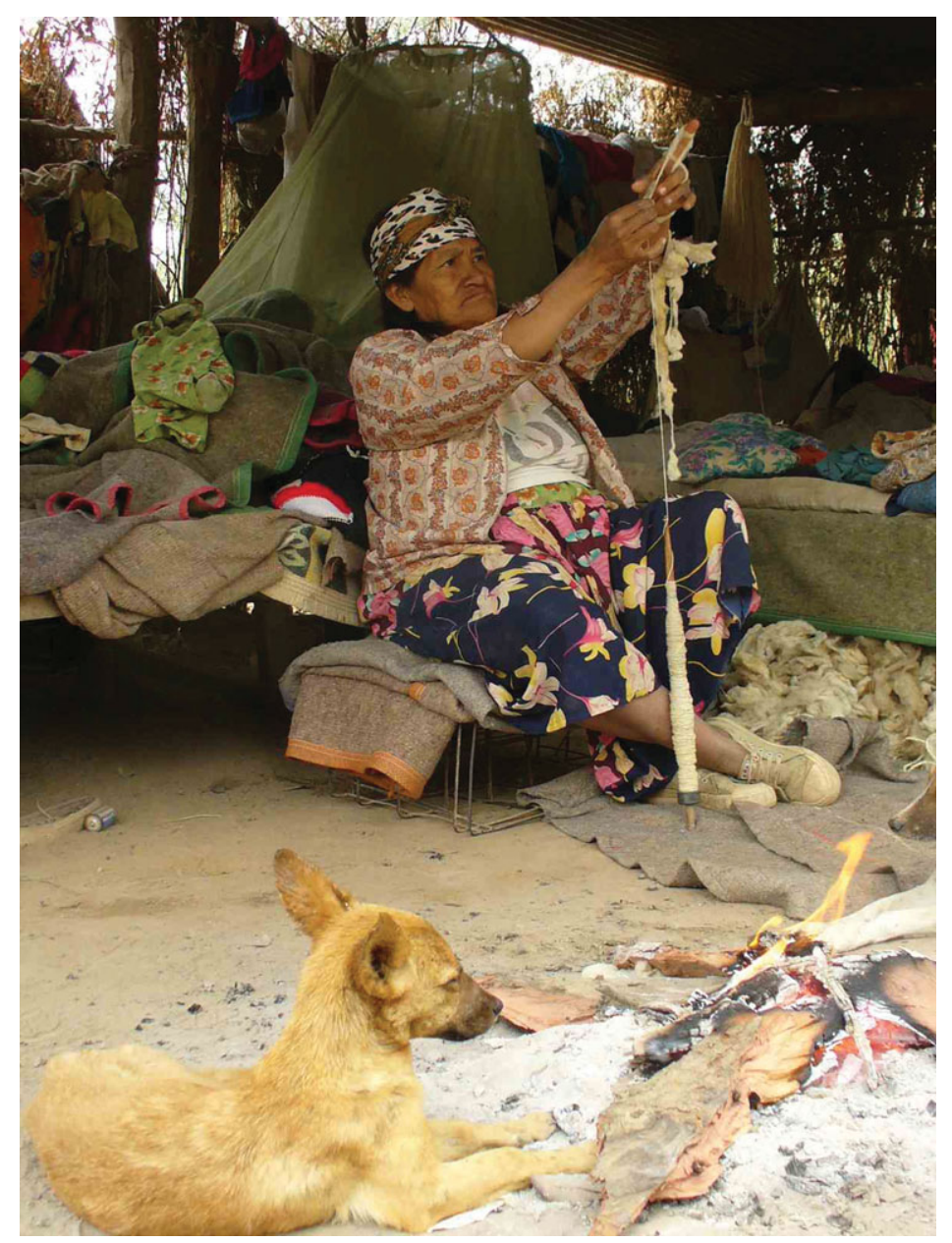

Figure 1. A Toba woman weaving. Photo: Cecilia Gómez.

understanding of the Pleiades analogous to that of the Abipones and the old Mocovies, two other linguistically related groups in the Chaco; however, when they were asked what the term meant, their informants did not know how to answer.

In Misión Tacaaglé, the star cluster is generally identified with an old man by the Tobas and Pilagás. The existence of a mythical character of great importance was recorded as recently as the 1970s. It was represented by the Pleiades and named Dapi'chi both among the western Tobas (located by the Pilcomayo River, in a place called Monte Carmelo, some $12 \mathrm{~km}$ southeast of the town of Hito 1 in the province of Salta) and the Pilagá (located near a township called Fortin Soledad, roughly in the centre of the province of Formosa). An interviewee noted that this character was old and that he let 'the elders' know that he did not want to be called 'father' but 'grandfather'; then he told them his name: Dapi'chi (Tomasini 1976). It seems that Dapi'chi went into the sky after establishing the universal order, and for this reason he was regarded as a kind of guarantor of the cosmic order. He governs from 'home', at the third level of the skies. After the mythic inversion of the sky and the earth, he created (among other things) the rain and the river, announced the coming of the frosts, and established the morning Venus, called potakáe. He even gave the stars and asterisms their names: tuna, carob tree (Opuntia spp.); suri, rhea (Rhea Americana); tojo, way; and another bright star called Kotógoik (Tomasini 1976: 69-77, Idoyaga Molina 1989: 18-24). No testimony collected 
recently among the Western Tobas of the province of Formosa has clearly identified this asterism as 'the creator'. However, the role that he plays is clearly important: he is in charge of the frost and the cold, and he comes during June, which marks the start of the traditional annual cycle.

\section{The Western Tobas of the province of Formosa and Dapi'chi}

Among the Western Tobas of the province of Formosa, Dapi'chi is the 'owner' of the frosts, the one responsible for bringing the first frost, an 'old man' who starts to be seen in winter and who is closely related to the start of the annual cycle. For these Toba peoples, the annual cycle is divided into two periods, clearly defined. One of these periods is $n a^{\prime}$ wagaya 'Ga, which is a generic term associated with heat and includes the sub-periods 'wo?e, nia 'Ga, 'k?ap, nawo 'Go and no 'laGa. The second period, which will be analyzed in depth in what follows, is naqabia 'Ga, a brief season characterized by cold and frost. In the western calendar, naqabia 'Ga takes place during June and July, a period of drought and drizzle. This is a time when there is little to eat in the bush and, therefore, a good opportunity for fishing (Arenas 2003: 183-184). Even though the beginning of the year is marked nowadays according to the western calendar, i.e., at the beginning of January, the old Tobas recognize that according to 'the elders' the new annual cycle starts during the cold time of the year.

A number of environmental markers serve to indicate periods in the annual seasonal cycle. Thus, according to one old man, if the bird called a'hewa la'lo, 'a small hot coal of fire' (Pyrocephalus rubinus) appears, it means hot weather is coming since the lo' got, owner, of the bird is a 'hewa, the sun. On the other hand, the cold weather is indicated by another bird called palalo 'Go (Xolmis irupero). Something else that indicates if the cold period is either approaching or winding up is the position of the Pleiades in the sky during the night or at dawn.

The first appearance of the Pleiades in naqabia 'Ga on the eastern horizon at dawn signals the start of the frosts. Their heliacal rise, in other words, operates as a clear signal and takes place in the northeast just before dawn during June. The Tobas describe the moment when the asterism first appears by stating that Dapi 'chi is 'new'. As nights go by, during dawn, just before sunrise, Dapi'chi starts to gain altitude and moves northwest. The Tobas describe this situation as its 'ageing'. In fact, every night, just before sunrise, it reaches its highest altitude above the horizon further to the northwest, so it is believed that Dapi'chi 'starts to hide' or 'goes backwards'. Indeed, if it is closely watched as the following months go by, just before sunrise, it eventually reaches its highest altitude at culmination, after which it can be said that Dapi'chi starts to 'leave'. As more months pass, when it is observed just before sunrise, its altitude decreases and it moves towards the northwest horizon. Its cosmical setting takes place at the beginning of December. One of the Tobas explained that "Dapi'chi is the most important celestial being; it remains six months". This is consistent with the time difference between the heliacal rise in midJune and the cosmical setting around the beginning of December. A consequence of the 'ageing' of the asterism is that when it reaches its highest altitude just before dawn, this provides a clear indication that the frosts are coming to an end. This usually happens at the beginning of September, during nawo 'Go, when some trees start to sprout. This time remained highly important in the traditional calendar since it marked the beginning of a new annual cycle.

The heliacal rise of Dapi'chi, then, proclaimes the new annual period, but the new cycle only actually starts when the asterism is first seen to reach its highest altitude (just before dawn). The data collected during this study, and the observations made together 
with the Tobas, support this view: the new cycle is anticipated as soon as Dapi'chi appears in the pre-dawn sky, whereas once it can be seen to reach its highest altitude in the sky, from the beginning of September onwards, it is said that the new cycle has already started. The Tobas consider that Dapi ${ }^{\prime} c h i$ is especially visible during the winter. However, it is important to emphasize that the Pleiades can be seen in the sky not only during naqabia 'Ga, the cold period in the annual cycle, but also during the hot period (for example in February), just after the sun goes down. At this time, the Tobas do not assign it any importance and even some may contend that the star cluster in question is not Dapi'chi. Only a few acknowledge that, even during the hot nights of the annual cycle, the Pleiades can be seen. Other Tobas groups give it the name $M a^{\prime} p i k$, carob tree, at this time.

\section{The crown (noko 'pa) of Dapi'chi}

The informants also explained that if Dapi'chi carries noko 'pa, there will be a frost. According to Tebboth $(1943: 178,194)$, no indicates 'his' while coipá means 'crown'. This suggests that noko 'pa means 'his crown'.

According to traditional cosmology, the frost is under Dapi'chi's control. The crown is related to Dapi 'chi at the moment of its heliacal rising and at which time it can be clearly perceived. According to the Tobas, its splendor can only be seen when you look at the star cluster from a flat field free of trees, so as to be able to see it clearly when it is at very low altitude. The observations should take place just before sunrise, when the Pleiades start to move away from the horizon. The crown of Dapi 'chi remains inseparable from the asterism, but the Tobas clarify that it can be better appreciated in winter, when it is near the horizon: "when the sky is closer to the land". On these occasions, the stars that compose the asterism seem to alter their brightness, to change their color and even to shift their position. These effects are noticeable when the stars that compose the asterism twinkle or blink. According to the Tobas, when 'the stars twinkle' their light changes their color ('red, pink, green'); this phenomenon is related to the color of air carnations (Tillandsia spp.-Bromeliaceae) when they are in flower (see Fig. 2). This similarity is reflected in the homonymy Dapi'chi (meaning both the

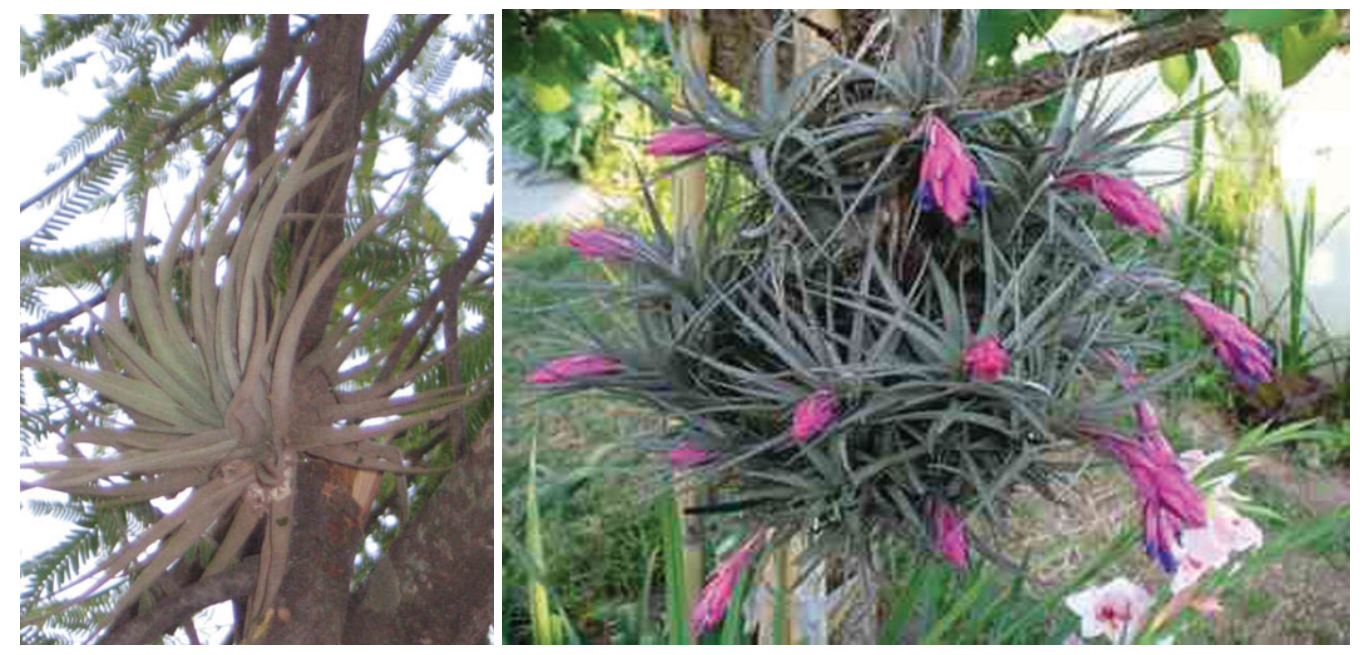

Figure 2. Air carnations: Left: Photo by Cecilia Gómez; Right: in flower (from http://www.infojardin.com/foro/showthread.php?t=42825) 
asterism and its colored crown, when it is near to the horizon, and air carnation). The Tobas also say that the cluster has a crown because of the shape of the asterism, which consists of a number of bright spots in the sky. These spots can be clearly identified but, at the same time, they belong to a larger unit that moves together and never loses shape. So it seems to be of great importance to consider the influence of different atmospheric conditions when viewing the asterism, particularly since key observations of the cluster are undertaken during its heliacal rising, when it is at low altitude very close to the horizon. The Tobas explain the importance of the crown of Dapi'chi in the following terms:

"Dapi'chi, man that has noko'pa (...) an old man of my land who has a crown (...) There was an old man who used to develop noko 'pa in the shape of a suri [Rhea americana] and he used it as Dapi'chi does. This man was very important."

To sum up, Dapi'chi has noko 'pa, a crown, since it is an important characteristic; this importance, as we shall see, is closely related to the notion of leadership.

\section{Dapi'chi as a leader}

One of the old men explained that Dapi'chi is haliaG a 'nek, a leader, because he knows about the other stars and, besides, he "has lots of work to do". He certainly has several chores: he administers the frost, the cold in general, and the southern wind or kola 'waik. At the same time, it is said that his appearance brings a new period of abundance: it is believed that $D a p i$ 'chi is the responsible for the arrival of 'wole and also his halia $a$ ' nek. In other words, Dapi'chi is 'the one in charge of making everything new'. It is important to realize that the seasonal period 'wole starts in December, when it is easy to find carob in the bush. According to all the testimonies collected, we are also talking about 'an important man'. The Tobas explain that he possesses a crown, which is the symbol of the old man who has authority and is wiser than the rest of the people. In fact, 'old age' is a prerequisite for a halia $a^{\prime} n e k$, since from the Toba point of view, 'there are older people who lead and know all'. One of the old men commented that in the old times, the old man 'was the governor and the other people were like kids'; another younger informant added that Dapi'chi is closely linked to halia $a^{\prime}$ 'nek as a leader in war and that everything that showed strength was given the name of the asterism.

When the term halia $a^{\prime}$ 'nek is used or explained, the Tobas seem to be referring to the idea of leadership as it was conceived in the old times, despite the fact that the concept has clearly changed throughout the years. A good haliaGa'nek had to be generous, be a good orator, have the powers of a pioGo 'nak (shaman), have the ability to share and, above all, be a good warrior. This predisposition towards war accounts for the requirements each haliaGa'nek had to meet. According to Métraux (1937: 390-391), the position of halia $a^{\prime}$ 'nek was hereditary, but a son was only able to inherit his father's position if he showed himself brave enough at war; otherwise his younger brother would inherit. In another text, the same author (Métraux 1946: 303-304) explains that in the case of the peoples who lived near the Bermejo and Pilcomayo rivers, the leadership position was occupied by the one who was best able to show the so-called skills. However, he then explains that among the Tobas, even though the position of the leader is not entirely hereditary, sons or close relatives of the previous leader usually inherit. They must show everyone that they are brave enough and that they possess the appropriate skills.

\section{War}

In former times, a halia $a^{\prime}$ 'nek was in charge of deciding when to start a war. Beforehand, he had to invite the rest of the leaders to a drinking bout, where the topic was discussed. Drinking together had a serious purpose: this kind of occasion was used 
to establish a common framework for the alliance of political groupings. These were mainly established during times of war, but they could also serve other purposes, such as marriage alliances (Braunstein 2008).

One of the interviewees shared the information that the ya'kachi, old men, got together in what was called an 'assembly' in order to hold 'proper' discussions. When an invitation was issued, it was understood that la'taga, chicha (maize beer), was to be drunk. (Note that, according to Tebboth (1943: 191), the term for 'cite', 'assemble' or 'call' is latagan.) During the meeting they tried to reach agreement and choose the leader of the expedition. According to Métraux (1946: 313), if the halia $a^{\prime}$ 'nek was too old, one of his relatives, the most assertive warrior, would occupy his place. There were several leaders and each of them had 'his power': they could talk with animals, interpret dreams, etc. However, in war times, a chosen leader was put in charge of the expedition. On a smaller scale, leadership was defined within each local group taking into account kinship relations, while the relationships between physically separated groups were determined according to a complex system of preeminence and symbolic attributes that defined the nature of the liaisons between the representatives of the different local groups. These criteria were diplomatic in nature and were used to maintain the stability of the alliances. The ritualistic framework of the institutional system featured not only the traditional drinking bouts but also war trophies, particularly the scalps of dead enemies, which functioned as a fixed, symbolic indication of socio-political hierarchies (Braunstein 2008). On the other hand, it is important to mention that the power that these war leaders showed was in stark contrast to the lax and blurred image they used to maintain during periods of peace (Métraux 1946: 313). To sum up, when interviewing the Tobas about a leader's competence, war was constantly mentioned. Thus, eloquence is considered to be a basic skill of a leader because it is needed in order to persuade the rest of the haliaGa'nek to organize war raids. This entailed inviting them to a drinking bout, and showing due generosity by giving them cows, horses, weapons, food, etc. It was necessary to have some of the powers of a shaman so as to be able to read both the auspicious and inauspicious 'signs' before going to war. In the battlefield, it was essential to show sufficient courage to kill the enemy and get na'kaik lo1ok, scalps. A successful leader had to prove his generosity by giving away part of the booty or keeping at least one of the prisoners (Métraux 1937: 397).

It is important to take into account the fact that, at the beginning of the 20th century, Tobas subsistence depended on the flood cycles of the Pilcomayo River, and also on the availability of water in the region far away from the river (Mendoza 2002: 116, 127, 131). It was essential that those groups who lived far from the river had some water at their disposal, either from lakes or streams. When the volume of the rivers started to decrease, and so there was no longer a large number of fish, the groups that were settled far from the river-Tobas as well as others - reached agreement with those groups that were nearer the river as to the fishing sites each of them could make use of. However, the building of river palisades, especially during a time of drought, became one of the main causes of conflicts among the different indigenous groups. These fences - built at a time of year called yamta'le naqabia' $\mathrm{G} a$ (prior to the coldest period in the annual cycle) and also at the start of a period called nawo 'Go (when the cold spell came to an end) - stopped fish getting to the lower parts of the river, thereby cutting off a major food source for the peoples who inhabited these areas; these groups then tried to destroy the palisades, and war ensued and escalated (Nordenskiöld [1912] 2002: 119, Mendoza 2002: 133). This was the appropriate moment for the figure of the halia $a$ 'nek to exert his influence, motivated not only by material gain but also by the opportunity to gain prestige and social authority, all of which are well-known triggers of war. 


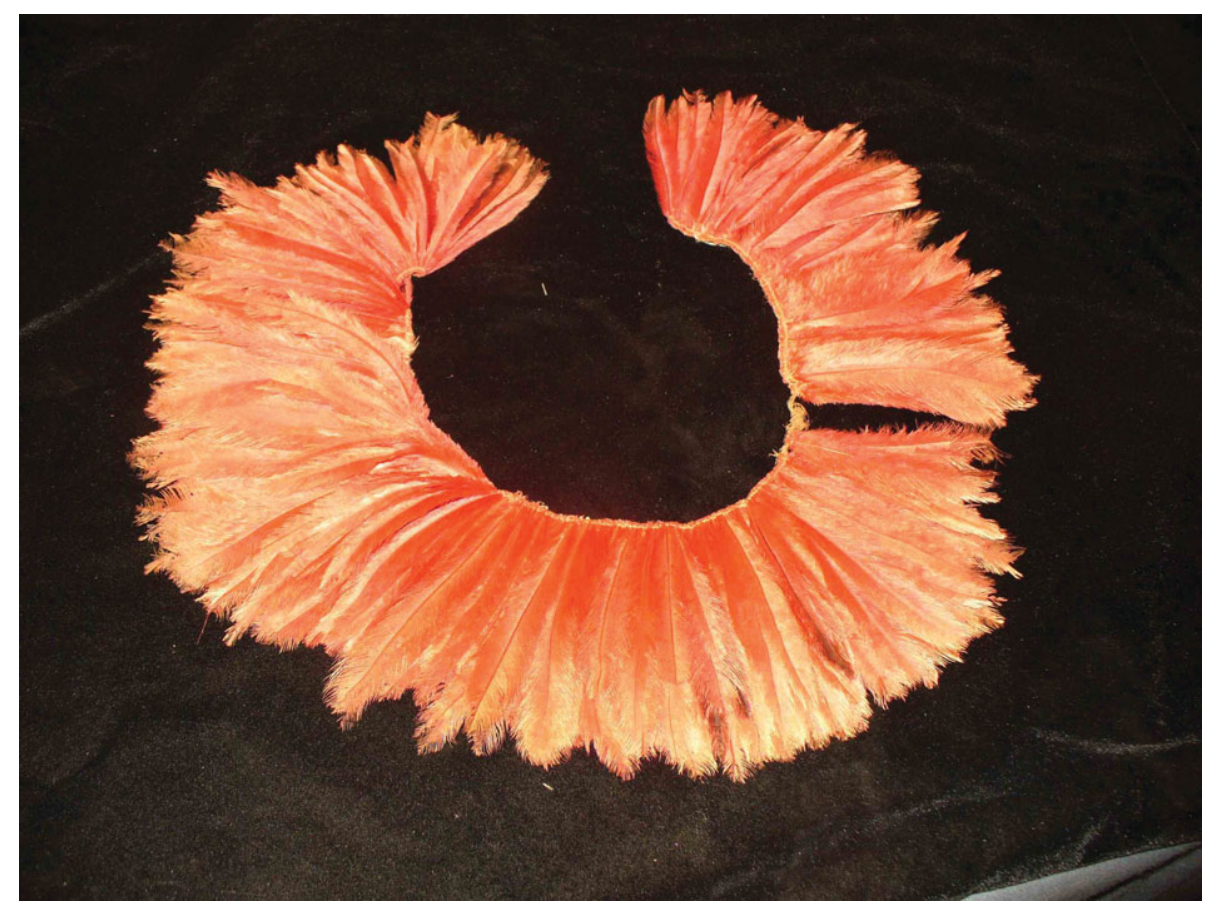

Figure 3. A Toba crown of red feathers (Museo Etnográfico Juan B. Ambrosetti, n. $35-472 / 41049)$.

Before going to battle, the warriors painted their bodies in red and black stripes; they wore feathers and shirts woven in caraguatá (Bromeliaceae), and sometimes even tiger- or anteater-skin jackets. Red crowns (see Fig. 3) were worn by those men who had killed an enemy beforehand: "Only those who had killed an enemy and owned two scalps were authorized [to wear red feathers on their crowns]" (Arnott 1934a: 498). The warriors walked through the night until they reached where their enemies lived, then moved slowly and, as the sun started to rise, attacked them by surprise (Métraux 1933; 1937: 395-396), while they were still sleeping (Métraux 1946: 314). The objectives were essentially to cut scalps from dead enemies, to take property, and to capture women and children.

The evidence suggests there were connections at various levels between Toba warfare and the Pleiades. First, the attacks took place at a time of year when there was shortage of resources (Arnott 1934b: 496), which was also the time when Dapi'chi was prominent in the sky. On these occasions, the warriors and the halia $a^{\prime}$ 'nek bore clear insignia of their battle achievements and, therefore, of their social status. These included diadems or crowns and body accessories made of red feathers from the flamingo or red-legged stork (both of which are connected to aquatic life, a fact that is significant because the conflicts were related to the use of the river's resources and fishing sites). There are various reasons for positing a meaningful parallelism between these marks of prestige and the Pleiades: the colors of the crown of Dapi'chi during its heliacal rising; the red feathers used for the diadems of the halia $a^{\prime} n e k$; and the shape and colour of the plant that carries the same name as the asterism and which appears during the worst drought of the year. In other words, the frequency of associations between the Pleiades and a series of phenomena such as war ornaments, the drought, and the reasons behind the war raids, argues that these had deep significance. 


\section{Conclusion}

To sum up, the evidence suggests that significant relationships connect the following: the time when Dapi'chi becomes 'new' in the sky, the frosts, the time of shortage of resources during the annual cycle, air carnations (Tillandsia spp.-Bromeliaceae), war ornaments such as crowns (noko'pa) made of red feathers, the timing of attacks and the vital resources needed for the survival of the group. Dapi'chi appears with noko 'pa, his crown, at the coldest time of the year when resources are scarce and he is in charge of fostering a store of seeds and bringing about the subsequent periods of abundance such as 'wole. At that time the asterism seems to disappear in the firmament or else transforms into another asterism representing a resource that is always present in abundance: carob. During the time of scarcity, the role and attributes of the warrior leader also emerge, noko 'pa the red crown being the characteristic that stands out. The halia $a$ 'nek leads the group into war in order to obtain the resouces necessary for their survival. After fighting, his role as leader becomes blurred and diluted, just as the asterism symbolically associated with these qualities - Dapi ' $c h i$ - disappears in the sky.

\section{Acknowledgements}

I am grateful to Dr Diego Villar and Lic. Sixto Giménez Benítez for their critical insights on several drafts of this paper, and to Clive Ruggles for the careful editing of the text.

\section{References}

Arenas, P. 2003, Etnografía y Alimentación entre los Toba-Ñachilamole\#ek y Wichi-Lhuku'tas del Chaco Central (Argentina), Dunken, Buenos Aires.

Arnott, J. 1934a, Los toba-pilagá del Chaco y sus guerras. Revista Geográfica Americana, 1(7), 491-501.

Arnott, J. 1934b, La magia y el curanderismo entre los toba-pilagá del Chaco. Revista Geográfica Americana, 2(14): 315-326.

Braunstein, J. 2008, Muchos caciques y pocos indios. Conceptos y categorías del liderazgo indígena chaqueño. In J. Braunstein \& N. Meichtry (eds), Liderazgo, Representatividad y Control Social en el Gran Chaco, Editorial Universitaria de la Universidad Nacional del Nordeste, Corrientes, pp. 3-31.

Idoyaga Molina, A. 1989, Astronomía pilagá. Scripta Ethnologica, Supplementa 9, 17-28.

Lehmann-Nitsche, R. 1924, La astronomía de los Tobas. Revista del Museo de La Plata 27, $267-285$.

Lehmann-Nitsche, R. 1924/5, La astronomía de los Tobas (segunda parte). Revista del Museo de La Plata 28, 181-209.

Mendoza, M. 2002, Band Mobility and Leadership among the Western Toba Hunter-Gatherers of Gran Chaco in Argentina, Edwin Mellen, New York.

Métraux A. 1933, La guerra primitiva en el Chaco, La Prensa (Sección Tercera), Buenos Aires, January 8, 1933.

Métraux A. 1937, Études d'ethnographie Toba-Pilagá (Gran Chaco). Anthropos 32, 171-194, 378-401.

Métraux A. 1946, Ethnography of the Chaco. In J. Steward (ed.), Handbook of South American Indians, vol.1 (The Marginal tribes), Smithsonian Institution, Washington, pp. 197-370.

Nordenskiöld, E. [1912] 2002, La Vida de los Indios. El Gran Chaco (Sudamérica), APCOB, La Paz.

Tebboth, T. 1943, Diccionario Toba. Revista del Instituto de Antropología de la Universidad Nacional del Tucumán 3(2), 35-221.

Tomasini, A. 1976, Dapichi, un alto Dios uránico de los Toba. Scripta Ethnologica 4(1), 69-87. 